Огляди літератури, оригінальні дослідження, погляд на проблему, ювілеї УДК 616.36-006.327-06-003.326:616.61-036.12]-07-08-035

DOI 10.11603/1811-2471.2018.v0.i2.8474

\title{
ІНТЕНСИВНІСТЬ ФІБРОЗОУТВОРЕННЯ В ПЕЧІНЦІ ХВОРИХ НА НЕАЛКОГОЛЬНИЙ СТЕАТОГЕПАТИТ НА ТЛІ ОЖИРІННЯ І-ІІ СТУПЕНІВ ТА ХРОНІЧНУ ХВОРОБУ НИРОК
}

\author{
๑О. С. Хухліна, А. А. Антонів, О. Б. Кузьмінська, О. Д. Ляхович, О. Є. Мандрик \\ ВДнЗ України «Буковинський державний медичний університет», Чернівці
}

РЕзЮМЕ. Мета роботи - дослідити біохімічні маркери фіброзу печінки при НАСГ, що розвинувся на тлі ожиріння I-ІІ ступенів та XXН I-ІІІ стадій.

Матеріал і методи. Обстежено 98 хворих на НАСГ на тлі ожиріння I-ІІ ступенів, у тому числі 52 хворих на НАСГ на тлі ожиріння I-ІІ ступенів (1 група) без супровідної XXH, 46 хворих на НАСГ на тлі ожиріння І-ІІ ступенів із коморбідною XXН І-ІІІ ст. (2 група). Контрольну групу склали 20 практично здорових осіб (П3О) відповідного віку та статі.

Визначення структурних змін паренхіми печінки та нирок здійснювали шляхом проведення ультрасонографічного (УСГ) дослідження. 3 метою кількісної оцінки змін ехогенності печінки використали метод еходенситометрії із обчисленням гепаторенального індексу (ГРІ). Біопсія печінки виконана 32 хворим на НАСГ із супровідною XXH I-III ст., 28 хворим на НАСГ без XXН. Біоптати печінки отримували шляхом черезшкірної чи лапароскопічної прицільної біопсії.

Результати. Встановлено, що коморбідний перебіг НАСГ із ХХН характеризується вищим ступенем стеатозу печінки (ГРІ у 1,3 раза вищий, порівняно з групою хворих на НАСГ $(p<0,05)$ ), та вищим діагностичним порогом значень гепаторенального індексу, який у сильній взаємозалежності корелює зі ступенем стеатозу печінки, визначеним за Steato-test ( $r=0,87 ; p<0,001)$.

При неалкогольному стеатогепатиті, що розвивається на тлі ожиріння та XXH I-III стадії, встановлено наявність у печінковій тканині фібротичних змін, які за біохімічним індексом фіброзу перевищують такі у хворих на НАСГ без коморбідності з патологією нирок. При НАСГ встановлено прояви переважно F0-F1 стадій фіброзу печінки, при НАСГ із супровідною XXН I-III стадії переважали F1-F2 стадії фіброзу печінкової тканини.

Висновки. У хворих на НАСГ на тлі ожиріння найчастіше спостерігали перицелюлярний фіброз (у $100 \%$ випадків), дещо рідше зустрічали фіброз перисинусоїдально типу (39,3 \%) та центролобулярний (35,7 \%) і у 10,7 \% спостерігали перипортальний та портальний фіброз печінки. У хворих на НАСГ на тлі ожиріння та XXH I-ІІІ ст. перицелюлярний фіброз також виявляли у 100 \% випадків, значний відсоток займали перисинусоїдальний (78,1 \%) та перивенулярний (68,8 \%) фіброз 3-ї зони, а також фіброз портального та/або перипортального типу 3 поодинокими септами (25,0\%).

КЛючОВІ СлОВА: неалкогольний стеатогепатит; ожиріння; хронічна хвороба нирок; фіброз печінки.

Вступ. Згідно з даними літератури, неалкогольна жирова хвороба печінки (НАЖХП) при прогресуванні призводить до розвитку як цирозу печінки (ЦП), так і гепатоцелюлярної карциноми, захворюваність на які на тлі НАЖХП істотно перевищує показники у популяції. Численними є спроби науковців щодо пошуку нових вірогідних біохімічних маркерів інтенсивності фіброзоутворення [1-5], підвищення діагностичної цінності, чутливості та специфічності існуючих методів та розробка методів впливу з метою гальмування зазначених процесів. Частота виникнення неалкогольної жирової хвороби печінки (НАЖХП) у популяції становить 20-40 \%, у хворих на ожиріння - 50$90 \%[2,3,6,7]$. Поширеність неалклгольного стеатогепатиту (НАСГ) у світі складає 10 \% (600 млн людей) $[2,6,7]$. За останні 5 років захворюваність на стеатогепатит в Україні зросла на 76,6 \% $[4,6]$. У 12-40 \% хворих на стеатоз печінки упродовж 8-13 років розвивається НАСГ із раннім ФП. У 25 \% з них розвиваються ЦП, ПКН (15 \%) чи прециротичні зміни (10\%) [2, 7]. У 7 \% хворих з компенсованим ЦП упродовж 10 років розвивається гепатоцелюлярна карцинома, а 50 \% з них потребують трансплантації печінки або помирають внаслідок ПКН $[2,5,7]$.

Важливою проблемою в Україні та світі сьогодні $є$ також хронічна хвороба нирок (ХХН), захворюваність на яку за останні роки зросла на $17 \%$. Понад 500 млн осіб у світі (кожен десятий дорослий) мають ураження нирок. Щороку мільйони хворих помирають від ускладнень, які $є$ наслідком не визначеної раніше патології нирок [8-10]. Незважаючи на високий рівень вивчення патоморфологічної картини та закономірностей прогресування фіброзу печінки при неалкогольному стеатогепатиті (НАСГ) на тлі ожиріння $[5,6]$, особливості фіброзоутворення у печінковій тканині при НАСГ за коморбідності з хронічною хворобою нирок (XXH) залежно від стадії вивчені недостатньо.

Мета дослідження - вивчити біохімічні маркери фіброзу печінки при НАСГ, що розвинувся на тлі ожиріння I-I ступенів та XXH I-III стадії.

Матеріал і методи. Обстежено 98 хворих на НАСГ на тлі ожиріння I-ІІ ступенів, у тому числі: 52 хворих на НАСГ на тлі ожиріння І-ІІ ступенів 
Огляди літератури, оригінальні дослідження, погляд на проблему, ювілеї

(1 група) без супровідної XXН, 46 хворих на НАСГ на тлі ожиріння I-II ступенів із коморбідною XXH I-III ст. (2 група). Контрольну групу склали 20 практично здорових осіб (ПЗО) відповідного віку та статі.

Визначення структурних змін паренхіми печінки та нирок здійснювали шляхом проведення УСг дослідження. 3 метою кількісної оцінки змін ехогенності печінки використали метод еходенситометрії із обчисленням ГРІ [8]. Еходенситометрію печінки проводили натще на апараті Ultima РА («Радмир» ДП АТ НДІРВ, Харків, Україна) із використанням конвексного датчика (частота 3-5 МГц) 3 подальшою цифровою гістографічною обробкою УЗ-зображень. Для обчислення ГРІ на апараті візуалізували праву частку печінки, розташовуючи датчик у сагітальній площині по середньоключичній лінії з виведенням у зріз правої нирки. На лінії, паралельній довгій осі правої нирки, вибирали дві ділянки з максимально можливою гомогенністю та без включення судин і біліарних трактів. Перша, розміром 3,5×4 см (зона А), локалізувалася поблизу передньої поверхні печінки. Другу ділянку, розміром 2×2 см (зона В), локалізували в кірковій речовині правої нирки між пірамідами. У кожній ділянці реєстрували цифровий гістографічний показник середнього рівня інтенсивності ехосигналу - MN. ГPI розраховували за формулою: ГPI = MNA/MNB [11].

Біопсія печінки виконана 32 хворим на НАСГ із супровідною XXН I-III ст., 28 хворим на НАСГ без XXH. Біоптати печінки отримували шляхом черезшкірної чи лапароскопічної прицільної біопсії. Свіжий матеріал фіксували протягом 22 годин у нейтральному забуференому 10 \% водному розчині формаліну, після чого здійснювали зневоднювання у висхідній батареї етанолу і заливку в парафін. 3 парафінових блоків на санному мікротомі виготовляли зрізи товщиною 6-7 мкм. Парафінові зрізи завтовшки 5 мкм монтували на неімуногенні предметні скельця SuperFrost®Plus (Germany). Морфометричні дослідження виконували з використанням програмного забезпечення «Інтеграл-2МТ» (м. Київ) на кафедрі патологічної анатомії ВДНЗ України «Буковинський державний медичний університет». Визначали площу незмінених гепатоцитів (ПГ, мкм²), площу сполучної тканини (ПСТ, мкм $^{2}$ ) та стромально-паренхіматозне співвідношення (СПС). Стадію фіброзу визначали за морфологічною класифікацією Е. Brunt (2000) із обчисленням індексу фіброзу (ІФ).

Статистичний аналіз отриманих результатів проводили відповідно до виду проведеного дослідження та типів числових даних, які були отримані. Нормальність розподілу перевіряли за допомогою тестів Лілієфорса, Шапіро-Уїлка та мето- дом прямої візуальної оцінки гістограм розподілу власних значень. Кількісні показники, які мали нормальний розподіл, представлені у вигляді середнє (M) \pm стандартне відхилення (S). Дискретні величини представлені у вигляді абсолютних та відносних частот (відсоток спостережень до загальної кількості обстежених). Для порівнянь даних, які мали нормальний характер розподілу, використовували параметричні тести з оцінкою t-критерію Стьюдента, F-критерію Фішера. У випадку ненормального розподілу використовували медіанний тест, розрахунок рангового U-критерію Манна-Уїтні, для множинного порівняння - Т-критерій Вілкоксона (у випадку дослідження залежних груп). Для проведення статистичного та графічного аналізу отриманих результатів використовували програмні пакети Statistica for Windows версії 8.0 (Stat Soft inc., США), Microsoft Excel 2007 (Microsoft, США).

Результати й обговорення. Ультрасонографічне дослідження печінки обстежених хворих виявило вірогідний ступінь гепатомегалії, середньозернисту трансформацію структури та мозаїчне ущільнення (гіперехогенність, «строкатість») паренхіми печінки внаслідок її запалення, а також істотний ступінь розвитку стеатозу печінки (значний відсоток дорзального згасання ехосигналу). У обстежених хворих спостерігали статистично достовірне зростання ГРІ ( $p<0,001)$. Так, медіана та 25-й і 75-й квартильні значення для ГРІ у ПЗО становили 1,13 (1,0-1,27), у 1-й групі - 1,92 (1,752,16), у 2-й групі - 2,44 (95 \% ДІ 2,27-2,61). Підвищення ГРІ асоційоване з кількістю накопичених ліпідів у паренхімі органа, про що свідчить наявність прямої статистично достовірної сильної кореляції між ступенем стеатозу (за даними Steatotest) та ГPI ( $r=0,87 ; p<0,001)$. У пацієнтів із НАСГ на тлі ожиріння зміни ехогенності печінки зумовлені наявністю неалкогольного стеатозу.

Для визначення діагностичної значущості ГРІ нами використано ROC-аналіз, згідно з яким зростання цього показника $\epsilon$ ефективним маркером діагностики НАСГ, при якому AUROC для ГРI становив 0,97 (95 \% ДІ 0,96-0,98; p<0,001). Порогове значення для ГРІ, при підвищенні якого діагностувався НАСГ, розраховано на рівні >1,49, а чутливість, специфічність, PPV та NPV відповідно становили 93,3\%; 100 \%; 100 \% та 72,8 \%. Аналіз результатів діагностичного тесту для хворих із коморбідним перебігом НАCГ та XXH вказує на те, AUROC для ГРI становила 0,99 (95\% ДІ 0,98-1,0; p<0,001), також зросли чутливість та NPV відповідно до 96,8 \% і 87,2% при розрахованому оптимальному пороговому значенні ГРІ >1,52. Для ГРІ відзначено помірне підвищення порогового значення паралельно зі зростанням діагностичної цінності. Це $є$ свідченням того, 
Огляди літератури, оригінальні дослідження, погляд на проблему, ювілеї

що підвищення ехогенності паренхіми печінки $\epsilon$ чутливим маркером УЗ-сигналу для детекції зростання ступеня стеатозу.

Згідно з отриманими результатами, серед обстежених хворих на НАСГ 1 групи нульова стадія фіброзу (F0) зустрічалася у 28,6 \% хворих, водночас у 42,8 \% хворих реєстрували вірогідні фібротичні зміни (F1) у печінковій тканині. У хворих на НАСГ 1 групи F2 стадію було зареєстровано у 17,9 \% обстежених, F3 - у 10,7 \%. Отже, найчастіше реєстрували фібротичні зміни F1 стадії.

У групі хворих на НАСГ 2 групи F0 стадія фіброзу спостерігалася у 9,4 \% обстежених. F1 стадія була зареєстрована у співвідношенні 28,1%, F2 37,5 \%, F3 стадія була зареєстрована відповідно у 25,0 \% хворих 2 групи. F4 стадії у цього контингенту осіб виявлено не було. Порівняльний аналіз розподілу обстежених хворих за стадіями фіброзу при НАСГ 2 групи показав максимальну серед груп порівняння частоту F2 та F3 (37,5 \% та 25,0 \%) стадій. Отримані результати вказують на участь XXH в індукції фіброзування печінкової тканини на тлі НАСГ і ожиріння.

Аналіз структури фібротичних змін, а саме їх локалізації та поширеності у печінковій тканині, вказує на наявність усіх видів фіброзу, притаманних хронічним дифузним захворюванням печінки: перицелюлярного, перисинусоїдального, центролобулярного та портального з елементами септального (при F3), однак вони зустрічалися із різною частотою та ступенем вираженості, залежно від коморбідності з ХХН. Так, у хворих на НАСГ 1 групи найчастіше спостерігали перицелюлярний фіброз (у 100 \% випадків), дещо рідше зустрічався фіброз перисинусоїдально типу (39,3 \%) та центролобулярний (35,7%), і у 10,7 \% спостерігали перипортальний та порталий фіброз печінки.

У 2 групі перицелюлярний фіброз також спостерігався у 100 \% випадків, значний відсоток займали перисинусоїдальний $(78,1 \%)$ та перивенулярний (68,8 \%) фіброз 3 зони, а також фіброз портального та/або перипортального типу з поодинокими септами (25,0\%).

Таким чином, у хворих на НАСГ із XXH I-III ст. було виявлено фіброз змішаного типу із переважанням перицелюлярного, перисинусоїдального, перивенулярного та фокального чи екстенсивного портального фіброзу 3 зони із вираженими ознаками паренхіматозної та стромальної реак- ції. у 25,0 \% випадків зареєстровано розширені, склерозовані портальні тракти з вогнищевим гіалінозом сполучної тканини. Центролобулярно візуалізувалися осередки лімфоїдно-гістіоцитарних інфільтратів (некроз), які поширювалися углиб печінкових часток. Отже, у хворих на НАСГ встановлено наявність фібротичних змін у печінковій тканині, інтенсивність яких зростає за коморбідної XXH I-III ст. Ступінь розвитку та поширеність (площа) фібротичних змін у хворих на НАСГ та ожиріння із коморбідною XXН перевищує такі у репрезентативній групі хворих на НАСГ із ожирінням без коморбідних захворювань.

Висновки. 1. Коморбідний перебіг НАСГ із XXH характеризується вищим ступенем стеатозу печінки (ГРІ у 1,3 раза вищий, порівняно з групою хворих на НАСГ, $\mathrm{p}<0,05))$ та вищим діагностичним порогом значень гепаторенального індексу, який у сильній взаємозалежності корелює зі ступенем стеатозу печінки, визначеним за Steato-test ( $r=0,87$; $\mathrm{p}<0,001)$.

2. При неалкогольному стеатогепатиті, що розвивається на тлі ожиріння та XXH I-III ст., у печінковій тканині встановлено наявність фібротичних змін, які за біохімічним індексом фіброзу перевищують такі у хворих на НАСГ без коморбідності з патологією нирок. При НАСГ встановлено прояви переважно F0-F1 стадій фіброзу печінки, при НАСГ із супровідною XXН I-ІІІ ст. переважали F1-F2 стадії фіброзу печінкової тканини.

2. У хворих на НАСГ на тлі ожиріння найчастіше спостерігали перицелюлярний фіброз (у 100 \% випадків), дещо рідше зустрічався фіброз перисинусоїдального типу (39,3 \%) та центролобулярний (35,7 \%), і у 10,7 \% спостерігали перипортальний та портальний фіброз печінки. У хворих на НАСГ на тлі ожиріння та XXН I-III ст. перицелюлярний фіброз також спостерігали у 100 \% випадків, значний відсоток складали перисинусоїдальний (78,1%) та перивенулярний (68,8 \%) фіброз 3 зони, а також фіброз портального та/або перипортального типу з поодинокими септами $(25,0 \%)$.

Перспективою подальших наукових досліджень у цьому напрямку є розробка методу ранньої діагностики фіброзування печінки за біохімічними маркерами фіброзоутворення при неалкогольному стеатогепатиті на тлі ожиріння та супровідної XXН I-III стадій. 
Огляди літератури, оригінальні дослідження, погляд на проблему, ювілеї

\section{ЛІТЕРАТУРА}

1. FibroTest for staging fibrosis in non-alcoholic fatty liver disease - authors' reply / D. Festi, R. Schiumerini, E. Scaioli [et al.] // Aliment. Pharmacol. Ther. - 2013. Vol. 37, No. 6. - P. 656-657.

2. From NAFLD in clinical practice to answers from guidelines / F. Nascimbeni, R. Pais, S. Bellentani [et al.] // J. Hepatol. -2013. - Vol. 59, No. 4. - P. 859-871.

3. Хухліна О. С. Неалкогольний стеатогепатит та гіпертонічна хвороба: особливості коморбідного перебігу, оптимізовані підходи до лікування : монографія / О. С. Хухліна, О. Є. Мандрик. - Чернівці, 2014. - 204 с.

4. Diagnosis and Management of Non-alcoholic Fatty Liver Disease: Practice Guideline by the American Association for the Study of Liver Diseases, American College of Gastroenterology, and the American Gastroenterological Association / N. Chalasani, Z. Younossi, J. E. Lavine [et al.] // Am. J. Gastroenterol. - 2012. - No. 107. - P. 811-826.

5. The Enhanced Liver Fibrosis (ELF) score: normal values, influence factors and proposed cut-off values / R. Lichtinghagen, D. Pietsch, H. Bantel [et al.] // J. Hepatol. 2013. - Vol. 59, No. 2. - P. 236-242.

6. Бабак О. Я. Профилактические мероприятия при неалкогольной жировой болезни печени: существует ли способ снизить риск развития заболевания? / О. Я. Бабак, Е. В. Колесникова, К. А. Сытник // Сучасна гастроентерологія. - 2013. - № 3 (71). - С. 103-109.

7. Gambino R. Meta-analysis: natural history of nonalcoholic fatty liver disease (NAFLD) and diagnostic accuracy of non-invasive tests for liver disease severity / R. Gambino, M. Cassader, G. Pagano // Ann. Med. - 2011. No. 43. - P. 617-649.

8. Evolving importance of kidney disease: from subspecialty to global health burden / K. U. Eckardt, J. Coresh, O. Devuyst [et al.] // Lancet. - 2013. - No. 382. - P. 158-169.

9. Baumgarten M. Chronic kidney disease: detection and evaluation / M. Baumgarten, T. Gehr // American Family Physician. - 2011. - Vol. 84, No. 10. - P. 1138-1148.

10. Cohen E. A longitudinal assessment of the natural rate of decline in renal function with age / E. A. Cohen // J. Nephrol. - 2014. - Vol. 27, No. 6. - P. 635-641.

11. Diagnostic value of a computerized hepatorenal index for sonographic quanification of liver steatosis / M. Webb, H. Yeshua, S. Zelber-Sagi [et al.] // Am. J. Roentgenol. - 2009. - Vol. 192, No. 4. -P. 909-914.

\title{
REFERENCES
}

1. Festi, D., Schiumerini, R., Scaioli, E., \& Colecchia, A. (2013). Letter: FibroTest for staging fibrosis in non-alcoholic fatty liver disease - authors' reply. Aliment. Pharmacol. Ther., 37 (6), 656-657.

2. Nascimbeni, F., Pais, R., \& Bellentani, S. (2013). From NAFLD in clinical practice to answers from guidelines. J. Hepatol., 59 (4), 859-871.

3. Chuchlina, O.S., \& Mandryk, O.Je. (2014). Nealkoholnyi steatohepatyt ta hipertonichna khvoroba: osoblyvosti komorbidnoho perebihu, optymizovani pidkhody do likuvannia: Monohraffia [Non-alcoholic steatohepatitis and hypertension: features of the comorbid course, optimized approaches to treatment: Monograph]. Chernivtsi [in Ukrainian].

4. Chalasani, N., Younossi, Z., \& Lavine, J.E. (2012). Diagnosis and Management of Non-alcoholic Fatty Liver Disease: Practice Guideline by the American Association for the Study of Liver Diseases, American College of Gastroenterology, and the American Gastroenterological Association. Am. J. Gastroenterol., 107, 811-826.

5. Lichtinghagen, R., Pietsch, D., \& Bantel, H. (2013). The Enhanced Liver Fibrosis (ELF) score: normal values, influence factors and proposed cut-off values. J. Hepatol., 59 (2), 236-242.

6. Babak, O.Ya., Kolesnikova, E.V., \& Syitnik, K.A. (2013). Profilakticheskie meropriyatiya pri nealkogolnoy zhirovoy bolezni pecheni: sushchestvuyet li sposob snizit risk razvitiya zabolevaniya? [Preventive measures for nonalcoholic fatty liver disease: is there a way to reduce the risk of the disease?]. Suchasna gastroenterol. - Modern Gastroenterolgy, 3 (71), 103-109 [in Russian].

7. Gambino, R., Cassader, M., Pagano, G. (2011). Metaanalysis: natural history of non-alcoholic fatty liver disease (NAFLD) and diagnostic accuracy of non-invasive tests for liver disease severity. Ann. Med., 43, 617-649.

8. Eckardt, K.U., Coresh, J., \& Devuyst, O. (2013). Evolving importance of kidney disease: from subspecialty to global health burden. Lancet, 382, 158-169.

9. Baumgarten, M., Gehr, T. (2011). Chronic kidney disease: detection and evaluation. American Family Physician, 84 (10), 1138-1148.

10. Cohen, E., et al. (2014). A longitudinal assessment of the natural rate of decline in renal function with age. $J$. Nephrol., 27 (6), 635-641.

11. Webb, M., Yeshua, H., \& Zelber-Sagi, S. (2009). Diagnostic value of a computerized hepatorenal index for sonographic quanification of liver steatosis. Am. J. Roentgenol., 192 (4), 909-914.

\section{ИНТЕНСИВНОСТЬ ФИБРОЗООБРАЗОВАНИЯ В ПЕЧЕНИ БОЛЬНЫХ НЕАЛКОГОЛЬНЫМ СТЕАТОГЕПАТИТОМ НА ФОНЕ ОЖИРЕНИЯ І-ІІ СТЕПЕНИ И ХРОНИЧЕСКОЙ БОЛЕЗНИ ПОЧЕК}

\author{
๑О. С. Хухлина, А. А. Антонив, О. Б. Кузминская, О. Д. Ляхович, О. Е. Мандрик
}

ВГУЗ Украины «Буковинский государственный медицинский университет», Черновцы

РЕЗЮМЕ.Цель исследования-исследовать биохимические маркеры фиброза печени при НАСГ, развившемся на фоне ожирения I-ІІ степени и ХБП І-ІІІ стадии. 
Огляди літератури, оригінальні дослідження, погляд на проблему, ювілеї

Материал и методы. Обследовано 98 больных НАСГ на фоне ожирения I-ІІ степени, в том числе 52 больных НАСГ на фоне ожирения I-ІІ степени (1 группа) без сопутствующей ХБП, 46 больных НАСГ на фоне ожирения III степени с коморбидной ХБП І-ІІІ ст. (2 группа). Контрольную группу составили 20 практически здоровыХ лиц (ПЗЛ) соответствующего возраста и пола.

Определение структурных изменений паренхимы печени и почек осуществляли путем проведения ультрасонографического (УСГ) исследования. С целью количественной оценки изменений эхогенности печени использовали метод еходенситометрии с вычислением гепаторенального индекса (ГРИ). Биопсия печени выполнена 32 больным НАСГ с сопутствующей ХБП І-ІІІ ст., 28 больным НАСГ без ХБП. Биоптаты печени получали путем чрескожной или лапароскопической прицельной биопсии.

Результаты. Установлено, что коморбидное течение НАСГ с ХБП характеризуется высокой степенью стеатоза печени (ГРИ в 1,3 раза выше, по сравнению с группой больных НАСГ, $(p<0,05))$, и более высоким диагностическим порогом значений гепаторенального индекса, который в сильной взаимозависимости коррелирует со степенью стеатоза печени, определенной по Steato-test ( $r=0,87 ; p<0,001)$.

При неалкогольном стеатогепатите, который развивается на фоне ожирения и ХБП І-ІІІ стадии, установлено наличие фибротичних изменений в печеночной ткани, которые по биохимическому индексу фиброза превышают таковые у больных НАСГ без коморбидности с патологией почек. При НАСГ установлены проявления преимущественно F0-F1 стадий фиброза печени, при НАСГ с сопроводительной ХБП I-III стадии преобладали F1-F2 стадии фиброза печеночной ткани.

Выводы. У больных НАСГ на фоне ожирения чаще наблюдался перицеллюлярный фиброз (в $100 \%$ случаев), несколько реже встречался фиброз перисинусоидального типа (39,3 \%) и центролобулярный (35,7 \%) и у 10,7 \% наблюдали перипортальный и портальный фиброз печени. У больных НАСГ на фоне ожирения и ХБП І-ІІІ ст. перицеллюлярный фиброз также наблюдался в 100 \% случаев, значительный процент занимали перисинусоидальный (78,1 \%) и перивенулярний (68,8 \%) фиброз 3-й зоны, а также фиброз портального и/или перипортального типа с одиночными септами (25,0\%).

КЛЮчЕВЫЕ СЛОВА: неалкогольный стеатогепатит; ожирение; хроническая болезнь почек; фиброз печени.

\title{
THE INTENSITY OF FIBROGENESIS IN THE LIVER IN PATIENTS WITH NON-ALCOHOLIC STEATOHEPATITIS ON THE BACKGROUND OF I-II DEGREE OF OBESITY AND CHRONIC KIDNEY DISEASE
}

\author{
๑O. S. Khuchlina, A. A. Antoniv, O. B. Kuźminśka, O. D. Liakhovych, O. Je. Mandryk \\ Bukovynian State Medical University
}

SUMMARY. The aim of the study - to investigate the biochemical markers of liver fibrosis in patients with NASH, which developed on the background of obesity of the I-II degree and chronic kidney disease (CKD) of the I-III stage.

Material and Methods. 98 patients with NASH on the background of obesity of the I-II degree were examined, including: 52 patients with NASH against the background of obesity of I-II degree (1 group) (without comorbid CKD), 46 patients with NASH on the background of obesity of I-II degree and CKD of I-III stage (2 group). The control group consisted of 20 practically healthy persons (PHP) of the corresponding age and sex.

The determination of structural changes in liver and kidney parenchyma was carried out by ultrasonographic (USG) investigation. In order to quantify the changes of echogenicity of the liver the method of echodensitometry with the calculation of the hepatorenal index (HRI) was used. Biopsy of the liver was performed on 32 patients with NASH with comorbid CKD of I-III stage, 28 patients with NASH without CKD. Liver bioptats were obtained by percutaneous or laparoscopic sight biopsy.

The comorbid course of NASH and CKD is characterized by a higher degree of liver steatosis (HRI in 1.3 times higher compared to the group of patients with NASH, $\mathrm{p}<0.05$ ), and the higher diagnostic threshold of the values of the HRI, which has a strong correlation with the degree of liver steatosis, determined by Steato-test $(r=0.87 ; p<0.001)$.

In patients with non-alcoholic steatohepatitis with comorbid obesity and CKD of I-III stage, fibrotic changes in the liver tissue were detected and these changes according to the biochemical index of fibrosis exceeded those in patients with NASH without comorbidity with kidney pathology. In patients with NASH, F0-F1 stages of liver fibrosis were detected, while with NASH on the background of CKH of the I-III stage, F1-F2 stages of fibrosis of the liver tissue predominated.

In patients with NASH, in the case of obesity, pericellular fibrosis (in $100 \%$ of cases) was observed most frequently, fibrous perisinusoidal type (39.3\%) and centrolobular (35.7 \%) were more rarely found, and peripheral and portal fibrosis of the liver was observed in $10.7 \%$. In patients with NASH on the background of obesity and CKD of I-III stage pericellular fibrosis was also observed in $100 \%$ of cases, a significant percentage was occupied by perisinusoidal (78.1\%) and perivenular (68.8 \%) fibrosis of the 3 rd zone, and also fibrosis of the portal and/or peripartal type with single septa (25.0\%).

KEY WORDS: nonalcoholic steatohepatitis; obesity; chronic kidney disease; liver fibrosis. 